\title{
Kopi Jahe Merah Khas Sumenep Madura di Desa Mulyoagung Jetis Kabupaten Malang
}

\author{
Ika Nuriyanti ${ }^{1}$, Ita Suhermin Ingsih ${ }^{2}$, Ratna Nikin Hardati ${ }^{3}$ \\ Universitas Islam Malang ${ }^{1,2,3}$ \\ ika.nuriyanti@unisma.ac.id ${ }^{1}$,ita.suhermin@unisma.ac.id ${ }^{2}$, ratna.nikin@unisma.ac.id ${ }^{3}$
}

\begin{abstract}
Home industry in Mulyoagung Village, Dukuh Jetis, Dau District, Malang Regency is engaged in micro business, namely The Making of Red Ginger Coffee. IRT "Yuli" has several problems, including: Red Ginger coffee production equipment is still simple, equipment has not been touched by science and technology, production results are not optimal, coffee sales income is not optimal, there is still a lack of understanding of hygienic and quality ginger coffee. There is a good seal and plastic to package the product, and there is also no proper economic analysis (marketing management) that is able to support the sale of ginger coffee products. Through this PKM, existing problems will be resolved by: Designing and making a ginger coffee grinder. Making a stamp tool for the ginger coffee brand. Providing training on bookkeeping and financial administration through POAC (Planning Organizing Actuating Controlling) concept. Providing training and mentoring to partners for hygienic ginger coffee making. The output targets are: 1) Manifesting a ginger coffee grinder tool so as to produce hygienic and clean ginger coffee; 2) Manifest the ginger coffee stamp as a packaging attraction for sales; 3) Providing training on management arrangements; and 4) Providing training for hygienic ginger coffee making.
\end{abstract}

Keywords: Coffee; Ginger; Poac; Home Industry.

\begin{abstract}
Abstrak
Industri rumah tangga di Desa Mulyoagung Dukuh Jetis, Kecamatan Dau, Kabupaten Malang bergerak di bidang usaha mikro yaitu pembuatan kopi jahe. IRT "Yuli" memiliki beberapa permasalahan antara lain: Peralatan produksi kopi jahe masih sederhana, peralatan belum tersentuh Iptek, hasil produksi belum maksimal, pendapatan penjualan kopi belum optimal, masih minimnya pemahaman tentang kopi jahe yang higienis dan berkualitas, belum adanya cap dan plastik yang bagus untuk mengemas produk, dan juga belum dilakukannya analisis ekonomi secara benar (manajemen pemasaran). Melalui PKM ini permasalahan yang ada akan diselesaikan dengan: Merancang dan membuatkan alat penggiling kopi jahe sehingga dapat menghasilkan bubuk kopi yang higienis dan bersih. Membuat alat cap untuk merk kopi jahe sebagai daya tarik kemasan pada penjualan. Memberikan pelatihan tentang pembukuan dan administrasi keuangan melalui konsep POAC (Planning Organizing Actuating Controlling). Memberikan pelatihan dan pendampingan tentang produk higienis. Target luaran program ini yaitu: 1) Memanifestasikan alat penggiling/selep bahan dasar kopi jahe sehingga dapat menghasilkan kopi jahe yang higienis dan bersih; 2) Memanifestasikan cap kopi jahe sebagai daya tarik kemasan pada penjualan; 3) Memberikan pelatihan tentang penataan manajemen melalui konsep POAC; dan 4) Memberikan pelatihan untuk pembuatan kopi jahe yang higienis.
\end{abstract}


Kata Kunci: Kopi; Jahe; POAC; Industri Rumah Tangga.

\section{A. PENDAHULUAN}

Desa Mulyoagung Dukuh Jetis tepatnya berada di Kecamatan Dau Kabupaten Malang terdapat 5 dusun yang terdiri dari 3.671 kepala keluarga, yaitu, Dusun Sengkaling, Jetak Lor (Utara), Jetak Ngasri, Dermo, dan Jetis (Malang, 2019). Usaha mikro yang berkembang di desa ini adalah di bidang peracik jamu, penjual cowek, kerajinan sandal, kerajinan kayu pinus, produksi krupuk makanan dan usaha kopi jahe sederhana, namun pengetahuan tentang pembuatan kopi jahe yang higienis belum begitu dipahami oleh warga. Di Jawa, jahe dikenal dengan jahe (Sunda), jae (Jawa), jhai (Madura), dan jae (Kangean) (Bermawie \& Purwiyanti, 2011). Jahe merah sendiri (Zingiber officinale var. rubrum) telah digunakan sebagai obat tradisional khususnya menyangkut penyembuhan luka karena kandungan oleoresin dan minyak atsiri yang tinggi (Sadikim, Sandhika, \& Saputro, 2018). Secara umum kandungan minyak atsiri rimpang jahe berkisar antara $1,07-1,09 \%$ pada semua komponen sifat kimia tanah Madura (Suryawati \& Murniyanto, 2011). Dari segi nutrisi, jahe mengandung kalori, karbohidrat, serat, protein, sodium, besi, potasium, magnesium, fosfor, zeng, folat, vitamin C, vitamin B6, vitamin A, riboflavin dan niacin (Aryanta, 2019).

Minuman instan jahe merah yang paling disukai adalah yang memiliki rasa manis, warna sedikit kecoklatan dan sedikit beraroma jahe (Prasetyo, Setiawan, \& Harismah, 2019). Pada pengabdian ini, jahe yang digunakan adalah jahe merah khas Sumenep, Madura. Selain di Sumenep, juga pernah dilakukan penelitian di daerah
Kabupaten Bangkalan yaitu di Desa Banyior Kecamatan Sepulu yang menunjukkan adanya potensi sebagai bahan pangan $54 \%$, dan sebagai obat tradisional $46 \%$ (Hotimah, Hayati, \& Hasan, 2019).

Jahe adalah tanaman yang paling banyak dimanfaatkan oleh masyarakat (Abidin, 2019). Kopi jahe merah di Desa Mulyoagung Dukuh Jetis merupakan salah satu mata pencaharian utama atau sampingan yang dilakukan oleh kaum perempuan. Tetapi pengetahuan tentang kebersihan yang kurang akan mengakibatkan kurangnya pengetahuan yang mendasari tentang: bagaimana cara memproduksi kopi jahe merah yang sehat, bagaimana menjaga kebersihan lingkungan saat memproduksi kopi jahe, bagaimana melakukan proses pengemasan kopi jahe merah yang bersih dan steril dan hal lain termasuk bagaimana memasarkan kopi jahe merah tersebut agar mendapatkan untung yang maksimal.

Kopi jahe merah memiliki kualitas yang baik, sehingga disarankan agar pengusaha kopi jahe merah memperhatikan kebersihan tangan maupun alat dalam pembuatan produk ini. Maka dari itu pembuat adalah pelaku utama yang sangat penting untuk mengecek kebersihan dari kopi jahe itu itu sendiri. Baik di lingkup industry rumah tangga, sampai lingkup hotel yang menerapkan prinsip, untuk dapat menghasilkan makanan dan minuman yang berkualitas balik, sehat disukai oleh tamu, hotel harus menerapkan higiene dan sanitasi (Auliya \& Aprilia, 2016). Karena itu pembuat harus menguasai pengetahuan tentang sikap dan perilaku yang baik dan sehat, dan hal yang perlu dilakukan adalah dengan memberikan ilmu pengetahuan tentang kebersihan dan penerapan teknologi 
dalam proses pembuatan kopi jahe merah.

Kurangnya pengetahuan akan pemikiran sehat akan dapat tertutupi apabila diberikannya pengetahuan konsep sehat melalui pelatihan dan pemahaman tentang kesehatan, yang didukung dengan desain dan pembuatan peralatan teknologi untuk proses produksi yang baik dan sehat. Oleh karena itu teknologi yang ditawarkan berupa alat selep kopi berkapasitas kecil untuk industri rumah tangga. Sehingga produsen tidak banyak membuang waktu dan tenaga untuk menyelep kopi keluar rumah. Hal ini dikarenakan peluang bisnis produksi jahe merah instan sangat bagus, karena jahe merah instan baik untuk dikonsumsi dengan maksud pencegahan bahkan pengobatan berbagai penyakit (Daulay, 2017).

Hasil dari pelaksanaan pengabdian ini diharapkan nantinya produsen kopi jahe dapat meningkatkan produksinya, baik secara kualitas maupun kuantitas dan kehygienisannya, dan juga mampu mengatur keuangan secara terpisah antara keuangan usaha dengan keuangan rumah tangga.

\section{B. PELAKSAAAN DAN METODE}

Kegiatan pengabdian masyarakat tentang pembuatan Kopi Jahe Merah Khas Madura ini dilaksanakan pada tanggal 10 Maret 2021 bertempat di lokasi produsen industri rumah tangga Kopi Jahe Merah Khas Madura di Desa Mulyoagung, Dukuh Jetis, Kecamatan Dau, tepatnya di Jl. Margobasuki.

Pelaksanaan pengabdian yang pertama adalah mensimulasikan cara pembuatan kopi jahe merah khas Madura, baik mulai dari pemilihan bahan baku yaitu kopi, jahe, dan gula, kemudian proses pengolahan bahan baku, dilanjutkan dengan proses penggorengan kopi dan jahe untuk kemudian diselep, sampai dengan pengemasan.
Kegiatan kedua adalah penyuluhan mengenai ke-hygienisan produk dan tata kelola pembukuan usaha, dengan mendatangkan dua narasumber dari Universitas Islam Malang.

Kegiatan pengabdian ini di ikuti oleh 12 orang yaitu dari phak produsen kopi jahe khas Madura.

\section{HASIL DAN PEMBAHASAN}

Fakta menunjukkan bahwa saat ini jumlah penjual kopi jahe terus berkembang proporsional dengan perkembangan kebutuhan masyarakat. Hampir setiap daerah di wilayah Malang sudah terdapat penjual kopi jahe. Maka untuk perkembangan kopi jahe menjadi sangat potensial, berprospek positif untuk meningkatkan budaya bangsa. Minuman kopi jahe merupakan minuman yang mempunyai peluang cukup bagus pada dunia usaha saat ini. Di lain hal, kelompok usaha ini memiliki prospek yang menjanjikan untuk pertumbuhan ekonomi daerah sekitar.

Usaha kopi jahe merah ini adalah usaha yang sudah ada sejak jaman dahulu, sehingga pembuatan kopi jahe merah yang dilakukan oleh para pembuat pasti memiliki ciri khas masing-masing. Pekerjaan ini diawali dari memilih bahan dasar seperti: kopi, jahe, dan lainnya. Bahan dasar yang digunakan juga perlu di lihat kualitasnya. Setelah itu bahan dibersihkan, jahe di iris kecil-kecil kemudian di jemur di bawah sinar matahari sampai kadar airnya berkurang antara $10-12 \%$. Kemudian campurkan dalam satu wadah penyangraian, dan diaduk menggunakan tangan, kemudian kopi dan jahe yang sudah tercampur disangrai sampai berwarna coklat tua. Kemudian diamkan sekitar 2 jam hingga kopi dan jahe yang sudah di sangrai dingin. Setelah dikiranya sudah 2 jam, ambil kopi jahe bisa di haluskan dengan di tumbuk atau di giling atau selep. Bubuk Kopi bisa di buat dengan tekstur halus 
atau agak kasar sesuai dengan permintaan konsumen. Dan terakhir, di kemas dandi masukkan masukan ke dalam plastik kemasan sesuai dengan permintaan.

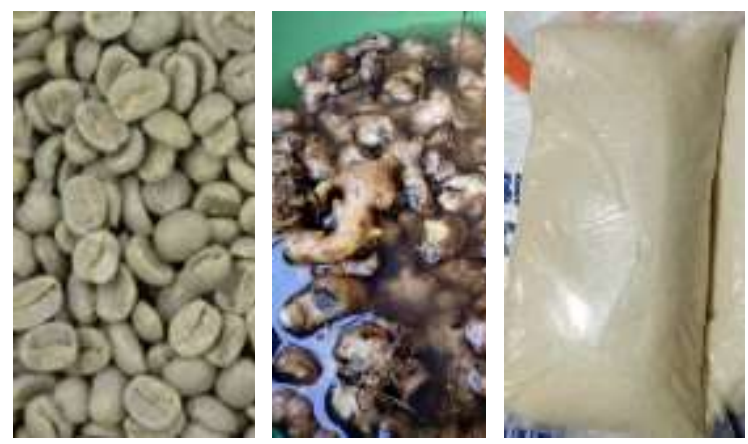

Gambar 1. Bahan Dasar Pembuatan Kopi Jahe Merah (Ki-Ka: Kopi, Jahe, Gula)

Alat penggiling kopi yang masih kurang tersentuh Iptek mengharuskan pembuat kopi jahe untuk pergi ke pasar menggilingkan kopi. Hal ini berdampak terhadap biaya dan kurang higienisnya bahan dasar kopi, sehingga berdampak pada kopi jahe yang dihasilkan menjadi kurang higienis sehingga tim pengabdi Bersama mitra bekerjasama untuk merancang sebuah alat mesin penggiling kopi yang dapat bermanfaat untuk meningkatkan hasil produksi.

Proses pembuatan kopi jahe di Desa Mulyoagung Dukuh Jetis adalah sebagai berikut:

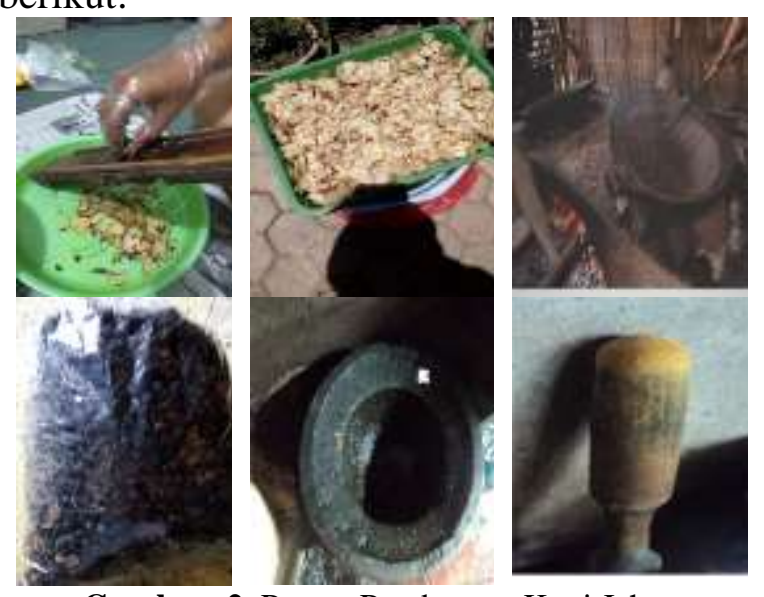

Gambar 2. Proses Pembuatan Kopi Jahe
Kurang higienisnya produksi kopi jahe sehingga untuk mengatasi masalah kehigienisan kopi jahe tim pengabdi mengupayakan dengan mendatangkan narasumber dari UNISMA sendiri yang ahli dalam gizi dan nutrisi.

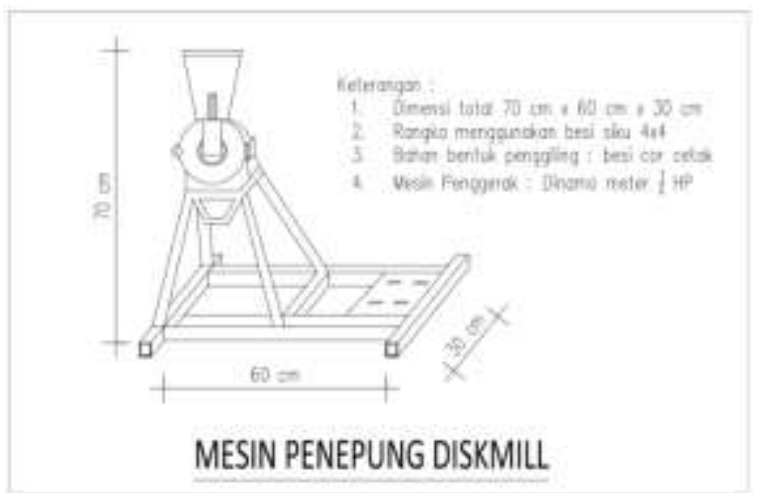

Gambar 3. Rancangan alat penggiling/selep kopi

Kegiatan pengabdian ini juga memberikan pendampingan atau penyuluhan mengenai kehigienisan produk kopi jahe dengan memberikan materi dengan judul "Pembuatan Kopi Yang Higienis".

Penyuluhan mengenai produk higienis ini menjelaskan bahwa ada 4 faktor yang berpengaruh yaitu: tempat, peralatan, orang, dan makanan.

Dari aspek faktor makanan, terdapat 6 prinsip atau 6P yang perlu di perhatikan dalam upaya penyehatan Makanan yaitu: Pemilihan bahan kopi, Penyimpanan bahan kopi, Pengolahan kopi, Penyimpanan produk kopi, Pengangkutan produk kopi, Penyajian produk kopi.

Beberapa istilah terkait dengan faktor makanan: 1) Kontaminasi/pencemaran, yaitu masuknya za tasing yang tidak di kehendaki ke dalam kopi, di bedakan menjadi 4 macam: pencemaran mikroba, pencemaran fisik, pencemaran kimia, pencemaran radioaktif, dan 2) Keracunan kopi, yaitu timbulnya gejala klinis suatu penyakit/ganguan Kesehatan akibat mengkonsumsi kopi yang tidak higienis. 
Pentingnya pengarsipan yang tertib dan rapi serta tata kelola administrasi akan sangat menunjang keberlangsungan kegiatan produksi. Begitu juga dengan melakukan analisis ekonomi secara benar untuk mendukung penjualan produk oleh mitra. Sehingga untuk mengatasi masalah tatakelola keuangan tim pengabdi mendatangkan narasumber dari FIA UNISMA guna memberikan pendampingan/ pelatihan terhadap tatakelola keuangan mitra dengan memberikan materi dengan judul "Pentingnya Membuat Pembukuan".

Kesalahan yang kerap dilakukan oleh pengusaha adalah mencampur aduk keuangan. Biasanya, pemula merasa kebingungan memisahkan antara keuangan perusahaan dan pribadi. Dengan begitu, maka akan ada kerancuan keuangan. Untuk itu, usaha sekecil apapun tetap harus melakukan pembukuan keuangan.

Beberapa masalah yang dihadapi oleh pihak produsen kopi jahe merah khas Madura dapat diselesaikan dengan langkah-langkah sebagai berikut:

1. Keterbatasan alat untuk menggiling kopi jahe, sehingga pembuat kopi jahe masih harus ke pasar untuk menggiling kopi sehingga menambah ongkos produksi dan kebersihan kopi yang di giling di pasar kurang terjamin. Hal ini berdampak terhadap kurang higienisnya bahan dasar pembuatan kopi jahe, sehingga berdampak pada kopi jahe yang dihasilkan menjadi kurang bersih. Dengan demikian pemecahannya yaitu merancang alat penggiling kopi jahe di rumah mitra, sehingga keuntungan bisa meningkat.

2. Kurangnya pengetahuan mitra tentang tata cara pembuatan kopi jahe yang benar dan higienis, sehingga diperlukan pemecahan dengan cara mendatangkan narasumber dari UNISMA tentang gizi dan nutrisi untuk memberikan pengetahuan terhadap mitra bagaimana cara membuat kopi jahe yang baik dan higienis.

3. Tidak adanya cap atau stiker pada kemasan plastik kopi jahe sehingga kemasan kopi jahe kurang menarik pada konsumen, dengan demikian pemecahannya yaitu dengan mendesain cap atau merek yang di tempal pada kemasan plastik kopi jahe sehingga tampilan kopi jahe akan lebih menarik.

4. Minimnya pengetahuan mitra pembuat kopi jahe tentang pengetahuan manajemen usaha dan tatakelola keuangan usaha. Untuk itu diperlukan solusi untuk meningkatkan kemampuan mitra melalui pelatihan dan pendampingan manajemen usaha dan pendampingan terhadap pelaksanaan tata Kelola keuangan usaha. Hal ini di lakukan dengan mendatangkan mendatangkan narasumber dari FIA UNISMA untuk memberikan pengetahuan pembukuan tentang keuangan terhadap mitra untuk meningkatkan keuntungan yang maksimal yang berkonsep pada Planning Organizing Actuating Controlling (POAC).

Hasil dari program kemitraan pada masyarakat yang telah dilakukan oleh tim pengabdi menjadikan IRT "Yuli" sebagai mitra pembuat kopi jahe menjadi lebih maksimal dalam memproduksi kopi jahe, kualitas dan kuantitasnya juga lebih maksimal, serta mitra sekarang juga memahami memproduksi dengan konsep yang higienis, tata Kelola keuangan mitra juga lebih tertata secara rapi.Kemajuan lain yang didapatkan oleh mitra dari hasil program kemitraan pada masyarakat ini berdampak pada: 1) Adanya alat penggiling/selep kopi jahe yang telah di desain dan tersentuh Iptek, serta hasil produksi dan pendapatan menjadi lebih maksimal dan optimal. 2) Pengetahuan yang telah diterima membuat Mitra dapat 
memenuhi standar kesehatan dalam memproduksi kopi jahe dan lebih higienis. 3) Adanya cap/stiker untuk mengemas produk sehingga produk kopi jahe lebih kelihatan menarik, dan 4) Sudah adanya analisis ekonomi secara benar (manajemen pemasaran) yang mampu mendukung penjualan produk kopi jahe.

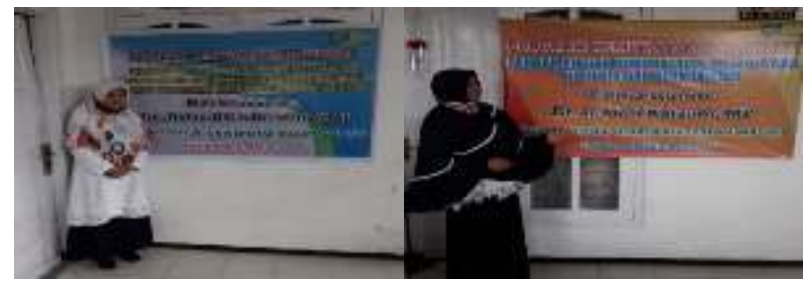

Gambar 4. Penyuluhan Tentang Kehigienisan Kopi Jahe \& Tata Kelola Keuangan

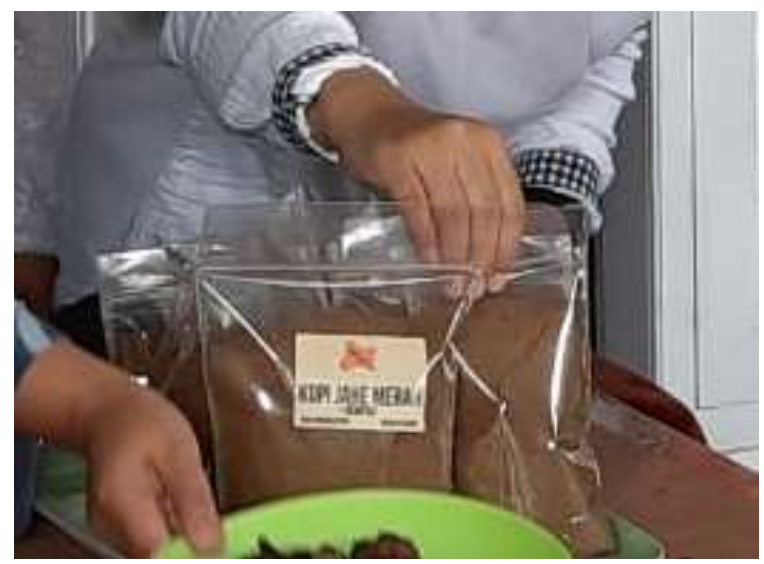

Gambar 5. Stiker/cap kopi jahe

\section{PENUTUP}

\section{Simpulan}

Metode program kemitraan kepada masyarakat yang di lakukan oleh tim pengabdi yaitu berupa metode pendekatan atau wawancara terhadap mitra. Hasil dari program kemitraan masyarakat ini: 1. Menghasilkan alat penggiling/selep kopi jahe guna meningkatkan hasil produksi. 2. Menghasilkan cap/stiker untuk kemasan kopi jahe sehingga lebih menarik. 3. Mendatangkan narasumber untuk pendampingan tentang kehigienisan kopi jahe. 4. Mendatangkan narasumber untuk pendampingan tentang tata Kelola keuangan. Hasil luaran pengabdian kepada masyarakat untuk dapat di publikasikan dalam jurnal pengabdian kepada masyarakat yang ber eISSN. Dimana mitra ini mampu menyerap tenaga kerja 3 sampai dengan 6 orang. IRT "Yuli" dijadikan sebagai mitra PKM.

\section{Saran}

Untuk pengabdian selanjutnya diharapkan adanya kerjasama yang baik antara tim pengabdi dan mitra guna mengetahui permasalahan yang di hadapi oleh mitra sehingga nantinya ada solusi yang dapat dipecahkan untuk menyelesaikan permasalahan mitra dengan demikian diharapkan terjalinnya hubugan yang baik antara pihak tim pengabdi Universitas Islam Malang dengan mitra akan tetap terjalin secara berkesinambungan (sustainable). Sehingga akan berdampak pada peningkatan hasil produksi kopi jahe.

\section{Ucapan Terima Kasih}

Terima kasih sebanyak-banyaknya kami ucapkan kepada IRT "Yuli” yang telah menyampaikan kendala pada produksi usahanya. Begitu juga kepada para penyuluh yang telah memberikan ilmunya kepada pelaku usaha Kopi Jahe Madura dan tim pengabdi. Besar harapan kami semoga pengabdian ini dapat bermanfaat.

\section{E. DAFTAR PUSTAKA}

Aryanta, I. W. (2019). Manfaat Jahe Untuk Kesehatan. E-Jurnal Widya Kesehatan,Volume 1, Nomor ; 2 , 3943. 
Abidin, Z. (2019). Pemanfaatan Tanaman Obat Dalam Mengatasi Keluhan Kesehatan Pada Kelompok Tani Tebu Jatiroto Lumajang. The Indonesian Journal Of Health Science ISSN (Print) : 2087-5053, 9-21.

Auliya, A., \& Aprilia, D. N. (2016). Pengaruh Hygiene Pengolahan Makanan Terhadap Kualitas Makanan di Hotel Aston Rasuna Jakarta . Jurnal Hospitality dan Pariwisata, Vol. 2 No. 2, 216-227.

Bermawie, N., \& Purwiyanti, S. (2011). Botani, Sistematika dan Keragaman Kultivar Jahe. Status teknologi hasil penelitian jahe, 1-19.

Daulay, A. S. (2017). Usaha Produk Minuman Kesehatan Jahe Merah Instan Di Kelurahan Binjai Kecamatan Medan Denai. Amaliyah: Jurnal Pengabdian Kepada Masyarakat Volume 1 No. 1, 15.

Hotimah, H., Hayati, A., \& Hasan, Z. (2019). Studi Etnobotani Jahe (Zingiber officinale) pada Masyarakat Desa Banyior Kecamatan Sepulu Kabupaten Bangkalan. BIOSAINTROPIS (BIOSCIENCE-TROPIC), 33-39.

Malang, B. P. (2019). Kecamatan Dau Dalam Angka 2019. Kabupaten Malang: BPS Kabupaten Malang.

Prasetyo, R. A., Setiawan, M. J., \& Harismah, K. (2019). Pembuatan Minuman Instan Jahe Merah (Zingiber officinale var. Rubrum) dengan Pemanis Stevia. Proceeding of The 8th University Research Colloquium 2018: Bidang Sosial Ekonomi dan Psikologi (pp. -). Purwokerto: LPPM Universitas Muhammadiyah Purwokerto.
Sadikim, R. Y., Sandhika, W., \& Saputro, I. D. (2018). Pengaruh Pemberian Ekstrak Jahe Merah (Zingiber officinale var. rubrum) terhadap Jumlah Sel Makrofag dan Pembuluh Darah pada Luka Bersih Mencit (Mus musculus) Jantan (Penelitian Eksperimental pada Hewan Coba). Berkala Ilmu Kesehatan Kulit dan Kelamin - Periodical of Dermatology and Venereology, 121-127.

Suryawati, S., \& Murniyanto, E. (2011). Hubungan Sifat Tanah Madura Dengan Kandungan Minyak Atsiri Dan Tingkat Kelarutannya Pada Jahe (Zingiber offocinale L.). Agrovigor: Jurnal Agroekoteknologi, 99-104. 